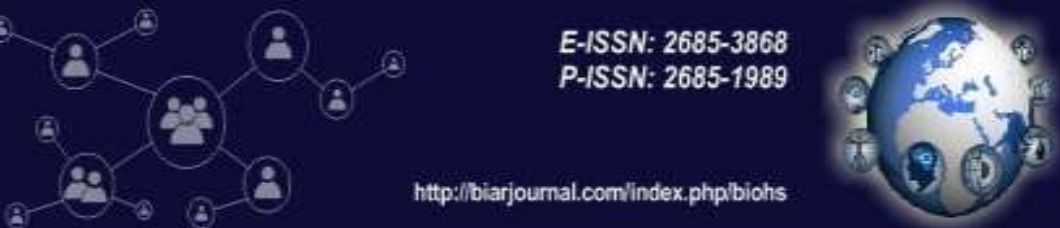

\title{
Analyzing the Similarity between Abagusii and Judean Conception of God as Reflected in the Book of Ruth
}

\author{
Charles K. Moywaywa ${ }^{1}$, Muhammad Ridwan ${ }^{2}$ \\ ${ }^{1}$ Department of Philosophy \& Religious Studies, South Eastern Kenya University \\ ${ }^{2}$ Universitas Islam Negeri Sumatera Utara, Indonesia \\ Email: ckinanga@seku.ac.ke
}

\begin{abstract}
:
The belief that God, or the Supreme Being, is the source of all that exists is common among a wide range of African communities that still retain a good measure of their traditional religiocultural heritage. The Abagusii of Western Kenya is one of the communities that has been exposed to and actually embraced the western culture. This notwithstanding, the Abagusii are still proud of their traditional customs and still maintain a good measure of these practices, either in their original form or with modifications. In this paper we examine the influence of belief in God on the day-to-day activities of the Abagusii and assess the similarity of their religiosity with that of the Judeans as reflected in the book of Ruth. The purpose of this work is to contribute to the on-going debate on inculturation by projecting a trajectory that appreciates the authenticity of all cultures. In comparing the similarity between Abagusii and Judean conception of and interaction with the divine, this paper covers the following key areas: the nature and function of God, human limitations, the relationship between God and humans, the notion of divine intervention, and the influence of religious consciousness on the daily life of the community and its members. The author is cognizant that the Book of Ruth may not provide a comprehensive picture of the Judean concept of God. But it provides a basis for a comparative study on the way community members utilized their religious awareness and identity to govern their daily lives.
\end{abstract}

\section{Keywords:}

Divine intervention; anthropocentricism; anthropomorphism; transcendence; immanence

\section{Introduction}

The Abagusii is a Bantu community living in South Nyanza region, western Kenya. They beighbour the Luo, the Kipsigis and the Maasai. They occupy the two counties of Kisii and Nyamira, though a good number of them also live outside their homeland; this last group prefer to be refered to as 'minto' in diaspora. This paper was prompted by the striking similarity between the cultural heritage of the Abagusii and the Judean culture as reflected in the book of Ruth. Judah is one of the tribes of Israel just as Abagusii is one of the tribes in Kenya and this makes the basis for comparative analysis.

The book of Ruth is a unique piece of literature. It is categorized as a historical book but contains plenty of moral lessons that it could easily pass for a prophetic or pentateucal literature. The most outstanding feature about this book is that it presents a people's religion, not as it ought to be - as is the case in most prophetic books and those of he Pentateuch, but as it actually is practiced on the ground, in real life. The book contains none of the symbols of communal worship nor does it deal with sermons or the like. There is however an allusion to political aspirations. Nonetheless, the narrative in this story is highly spiritual in its orientation. It portrays a people who are well grounded in their religious expectations and derive fulfilment 
from adhering to their religious traditions. The divine is directly mentioned only 23 times in the entire narrative (as God 3 times, as almighty once and as lord 19 times). There is also the mention of gods once. This makes the cumulative number of references to divinity to be 24 , placing it in number four after Ruth (123 times), Naomi (41 times) and Boaz (39 times). Although the name of God is mentioned only moderately in the narrative, the acknowledgement of his presence runs across the scripture mainly through the character of the protagonists and the nature and order of events. Thus, the book paints a spiritual environment that is similar to that of the African traditional society in general and the Abagusii traditional background in particular; it is a spiritual environment that is marked by pronounced stability and devoid of conflict (c/f Kemi 2020:615). The story may not be saturated with spiritual idioms and injunctions but it is clear from its contents that the Judeans, just like the Abagusii had an overriding concept of God.

\section{Review of Literatures}

From the narrative in the book of Ruth we learn something about the socio-political and geo-economic environment that forms the background of the story. That background fits well with many a place in Africa. This section examines some of the ways in which the sociopolitical and geo-ecomic environment depicted in Ruth's story compares with that of Gusiiland.

\subsection{Nature and Significance of the Family}

The concept of the family as the smallest social unit is implied in the book of Ruth (for example in Rt. 1:1, 3, 2:11, 3:9e, 4:12) as was also the case among the Abagusii (Nyabwari, 2011:64, 36, 99). The family was constituted by father, mother and children (Rt. 1:1, 2, 4:13), but close relatives were also considered part of the family (Rt. 2:8, 20, 3:10, 11, 12, 4:17). This extended form of family sytem was also the norm among the Abagusii. In terms of structure, the family, among the Abagusii was made up of homesteads. The number of homesteads depended on the number of wives a man had. Every wife lived in her own homestead but within the property of her husband. Polygamy was allowed in Gusii traditional culture. Monogamy was for those men who were not well endowed wealthwise.the material contained in Ruth however, appears heavily supportive of monogamy. Thus, the marital status of Boaz at the point of meeting and eventually marrying Ruth is not openly disclosed. Nevertheless, we can attribute this ommisiom to either author prejudices or thematic considerations rather than assume that polygamy was totally absent or largely uncommon.

Elimelech is portrayed as havimg a monogamous family. However, polygamy, as form of family, is alluded to (Rt. 4:10,11,13). Boaz appears to have lived only a few generations after the settlement of Israel in Caanan. Memory of the exodus experience was still somewhat fresh and this may explain the apparent sexual discipline among men at this time (Rt. 3:14) as compared to the generation in which David lived. Boaz sleeps overnight with Ruth but practiced self control, something David was sometimes unable to do. It can further be argued that the absence or rare mention of polygamous marriage in the book of Ruth may suggest its total exclusion from the Judean society of focus. Moreover, it may help to note that Boaz or his son Obed was most likely a contemporary of Elkanah. The latter hailed from the tribe of Ephraim and was polygamous $(1 \mathrm{Sm} .1: 1,2)$. This may imply that the Judeans probably embraced a higher form of morality than the other tribes. But we do not have sufficient evidence to make such a generalized view of the Judeans, given that the region of Bethrehem, the setting of this story, is only a small section of Judah. Furthermore there is nothing in the narrative to suggest that whatever we encounter in Ruth's story was the norm in all of Bethrehem. 
Another point of interlink between the Abagusii and Judean perception of the institution of marriage is in its functions. The main purpose for the family in both societies is the reproduction of children to propagate humankind (cf Rt. 4:10), thus ensuring continuous renewal of life (Rt. 4:14). The family is where individuals are reared from childhood unto adulthood (Rt. 4:17, 1:4). It also served as a source of identity for the individual (Rt. 1:1f, 4:10), a basic unit for socialization and a springboard for personal development (Rt. 4:6) and selfactualisation (Rt. 4:14). The husband is the head of the family (Rt. 1:1, 4:13) and is expected o provide for his family (Rt 1:9, 3:1). The Judean society practiced a slavery system and therefore married women were not expected to perform hard labour, unlike the case within the Gusii community. Among Judeans, wives were treated differently, a life devoid of hard labour- they were supposed to rest (Rt. 1:10) and be provided for (Rt. 3:1) by their husbands once they got married. This, however, does not necessarily imply that Judean women were all excluded from the productive life of Judea. Mong the Abagusii, women performed some heavy duty functions such as farmwork. Which in Judean milieu was left for servants. It appears that Elmelech was not as well-endowed as Boaz since there is no mention of Naomi having any servants inherited from her late husband while Boaz has all manner of servants and workers at his disposal. Ruth's role as a wife is simply to 'build a family' (Rt. 4:11), give birth and bring up children who could bring fame to her husband (Rt. 4:11). She is also required to show kindness to her husband (Rt. 1:10). Most of these characteristics of the family system in Judean set-up, tally with those of the Abagusii.

\subsection{Social Organization}

It is evident from the passage in Ruth that the Judean society is organized along clan lines but there is recognition of Judah as a tribe and Israel as a nation. The family (Rt. 2:12) is the smallest social unit and next is the clan (Rt. 2:1) then the tribe (1:1) and then the nation, Israel (Rt. 4:11, 2:12).. To this extend, the Judean social organization is in agreement with that of the Abagusii whose community is divided into various clans and sub-clans. In traditional Abagusii community, camps were common but these were established to serve as military bases. Generally, the community lived a settled life but in rural holdings. The idea of towns as is featured in the Judean experience was foreign to the Gusii setup. Towns in Gusiiland were only introduced during the colonial period. The Abagusii were organized along the village system but just like the Judeans, were highly ethnocentric in their civic orientation. Ethnocentrism is widespread in Africa (Diakhate 2020: 367).

\subsection{Geographical Features}

Gusii agriculture was practiced whereby livestock-keeping went alongside the tending of crops. This was the prevailing trend within the traditional Abagusii society. Their agricultural productivity, however, depended on on the adequacy and reliability of rainfall. When the raims fail, loses are incurred both in the farm (crops) and on the field (livestock).

Bethrehem of Judah appears to have geographical features similar to those of Gusiiland. There are hills. the area receives a fairly good supply of rain favouring some agriculture. However, Barley is associated with scanty supply of rain (Rt. 1:6, 22). This is unlike Gusiiland which receives a good supply of rain year-round. The Judean country is prone ro adverse climatic conditions and forces of nature such as famine and drought. This was also the case among the Abagusii. People. Ephrathata appears to be overly dependent on farming. There is no mention of livestock keeping, although we cannot conclusively rule out the practice. The book of ruth does not mention any animal.Although there is no mention of livestock in this passage, there is mention of cattle in Bethrehem during Jesus's birth. Also water is stored in containers inferring that water supply was through boreholes. Boreholes may have been unavailable in Gusiiland but water was normally sourced from nearby springs. The fetching of 
water from springs was done by women among the Abagusii but Judean culture seems to have placed this responsibility on the part of men.

\subsection{Economic Activities}

Other than agriculture, there is likely to have been in place trade and commerce. Selling and buying of property appears to have been a well-entrenched economic activity in Judah. This included disposal of ancestral land. Among the Abagusii, trade was in movable items such as livestock and foodsfaff. Tools such as hoes and pangas as well as weapons such as spears and swords was also practiced among the Abagusii (as may also have been in Judah). But the Gusii traditional culture did not allow selling of inherited fixed property such as land and houses.

\subsection{Political Organization}

After the Israelites settled in Canaan, they appear to have been disinterested in a centralized form of government. The suffering that their forefathers went through while in Egypt at the hands of Egyptian leaders called pharaohs may perhaps have caused Israelites generally to become averse to a centralized form of government. Before crossing the Jordan to take possession if Canaan, the mation of Israel was organized along ethnic lines with each of the twelve tribes being led by a leader. The leader of the tribe of Judah was Nashon, Boaz's grandfather. Leadership of the whole nation was deemed to be necessary only for purposes of national mobilization to accomplish a particular goal. Thus during the exodus the leadership of Moses was necessary to get the Israelites out of Egypt. Thereafter, Joshua took over the leadership in order to facilitate entry and settlement of this nation in Canaan. Joshua had been picked by Moses as his successor. But upon his death, Joshua had not appointed a designated successor. After his death, the conquest of Canaan continued but was now being undertaken at tribal level. Depending on the nature of the enemy, some tribes could join hands and face that enemy together for effective attack. But there was no unitary leader after the death of Joshua.

But as time went by and the surrounding nations continued to gain strenght, it became necessary that the Israelites should have a mechanism by which to nationally mobilize a combined force of troops to fight the enemy. That is when the idea of judges was born. Judges were important only when the nation was involved in a military campaign. During periods of tranquility, they were rendered irrelevant as each tribe reverted back to their respective echelons under their tribal leaders (the elders c/f Rt. 4:1-11). But the people who wielded a lot of power were the clan elders and each town had its own. Ephrathah was not an exception as demonstrated in the story og Ruth (Rt. 4:4,5). Abagusii were also organized into clans with each clan divided into villages and each village being governed by a council of elders who ultimately reported to clan chiefs called abaruoti (singular omorwoti). It appears likely that the concept of clan chiefs was initially absent among the Abagusii who may later have borrowed it from their luo neighbours the. At the national level, there was the institution of 'ritongo' or supreme council that was made up of eminent 'abagambi' or judges. This institution served as an appellate court where all the difficult matters were refered to for arbitration or interpretation.

\section{Results and Discussion}

\subsection{In Relation to the Nature and Function of God}

The Judean conception about the nature and function of God can best be understood by examining the theistic views expressed by various actors in the story. Note that according to the socio-cultural theory, various communities are guided by their surrounding environs to to formulate existential ideas that are specific to the nature of their adaptational needs (Rahmatirad, 2020:24). It is also important to note that the Judean view of God could be broader than expressed in the book of Ruth. The intention of this article however, is to 
annalyse the manner in which religious consciousness affects the daily life of believers. The discussions presented here proceed under the assumption that the religious consciousness of a people can be determined by observing the way these people conduct themselves in their daily life.

Obviously, the main point that the unknown author of the book of Ruth is seeking to make is that God can use afflictions to bless a person. That afflictions may visit you in multiplicity but that God's hand is always not too short to deliver blessings. Ruth is the most mentioned name in the text. Her view of deity is that of the universality of God. She says to Naomi, “... your God will be my God”. (Rt. 1:16). Naomi adds the perspective that God's universality implies that his operation is not limited only to the Israelite territory but goes beyond: “... but the lord has brought me back (from Moab) empty ..." (Rt. 1:21a). The Abagusii also believed that the Supreme being was universal in nature. His operations are without boundary. they were aware that other communities had a different name for God but still, it is the same God. National and patriotic sentiments are also evident whereby people view God in a possessive and exclusive manner. Thus, for Boaz, God is a God of Israel (Rt. 2:12). According to Nyabwari, Abagusii considered God, whom they called Engoro, as first and foremost, the God of the Abagusii, though he had sovereignity over other nations and territories as well. The latter attribute of God, as having jurisdiction over other lands, was interpreted to be at the interest of the Abagusii. Thus, the power of God was perceived in an ethnocentric manner.

Another attribute of God that is found in Ruth and which agrees with Gusii mentality is that God is transcendent. God is beyond question (Rt. 1:1, 21). Although priests are not mentioned in the Ruthan account, it can be deduced that Ephrathites were conscious of the place of priests in mediating between the people and God and that God cannot be seen (Ex. 19:21). But he is also immanent, since he blesses, "when Naomi heard in Moab that the Lord had come to the aid of his people" (Rt. 1:6). On arrival Boaz greeted the harvesters "God be with you" and the harvesters responded "The Lord bless you". This reflects that there was a basic belief that God was not too far to hear their prayers. Among the Abagusii, a similar view that God is both transcendent and immanent was common (Nyabwari, 2011). God also has such attributes as kindness (Rt. 1:8), is loving, (Rt. 1:6), is good (Rt 4:14) is almighty (Rt. :21), is self-existent and eternal (Rt. 3:13) and the object of praise (Rt. 4:14). The anthropomorphism of God is hinted in the book of Ruth. For example, while talking with Orpha and Ruth, Naomi laments “... the Lord's hand has turned against me”. The Abagusii also embraced a similar belief where God was viewed as having human-like features (Nyabwari, 2011).

\subsection{The Quest for an Appropriate Model for Inculturation in African Christianity}

There is need for African theologians to project a model of inculturation that appreciates the value of cultural pluralism. In a globalized context such as the one we currently live in, it could be counter-productive if theologians continue to perpetuate the notion that it is ok for oeople balkanize into various groups based on racial and cultural differences. If we choose a path that seeks to glorify one's culture at the expense of others. Such was the trend followed by some of the pioneer Euro-American missionaries. Hence advocating for a paradigm that favours a leaning towards African culture and away from the western culture is to commit the same error. African theologians have the onerous task of developing and promoting a model that is truly cogmitive of the authenticity of all human cultures. 


\section{Conclusion}

In conclusion, it is worth noting that humanity is in need of inter-religious harmony. For this reason, every effort must be made to identify and utilize those cultural items within our various communities that could be potentially uniting. It is apparent from the foregoing discussion, that the Hebrew and the African concept of God. This indicates that there are many things that are common between various communities which could be utilized to realize the much touted inter-religious and by extension, inter-communal harmony. It also points to the possibility that, ultimately, humanity is one.

\section{References}

Diakhate, Babacar, (2020).cultural Diversity, Ethnocentrism and Terrorism in Mukoma wa Ngugi's BlackStar Nairobi(2013). Britain International of Humanities and Social Sciences (BIoHS) Journal, 367-373.

Dupuis Jacques (1997). Towards a Christian theology of pluralism, Maryknoll, Orbis.

Gafney, W. (2010). 'Ruth', in H. Page et al. (eds.), The Africana Bible: Reading Israel's scriptures from Africa and the African diaspora, Minneapolis, Fortress, pp. 249-254.

Getui, Mary ed. (1998). Theological Method \& Aspects of Worship in African Christianity, Nairobi Acton.

Kemi, Anthony Emina, 2020. Ethno-religious conflict and the quest for peace in a plural society in Africa. Britain International of Humanities and Social Sciences (BIoHS) Journal, 613-622.

Mbiti J. S. (1990). African Religions and Philosophy, London, Heinemann.

- (1986). Bible and Theology in African Christianity, Nairobi, OUP.

- (1970). Concepts of God in Africa, London, SPCK.

Mugambi, J. N. K. Guy, Michael R. (2009). Contextual Theology Across Cultures, Nairobi, Acton.

Mugambi, J. N. K. (2002). Christianity and African Culture, Bairobi, Acton.

- ed. (1990). A Comparative Study of Religions. Nairobi, NUP.

Oduyoye, M.A. (2004). People of faith and the challenge of HIV/AIDS, Ibadan, Sefer.

Ogot, Bethwell A. (1976). The Economic and Social History of East Africa, Nairobi, Kenya Literature Bureau.

Parton, O. M. ed. (1976). Breaking Barriers; A Report of the Fifth Assembly of World Council of Churches, Nairobi, 1975, London, S.P.C.K.

Phiri, I. A. (2006). 'Ruth', in T. Adeyemo (ed), Africa Bible commentary, pp. 319-324, World Alive Publishers, Nairobi.

Rahmatirad, Mabobeh, (2020). A review of the socio-cultural theory. Siasat Journal. 23-31.

Rothwell, J. (2004). In the Company of others. 2nd ed. New York, McGraw Hill.

Waliggo Johnmary (1986). Inculturation: Its Meanig and Urgency, Nairobi, St Paul Publication Africa. 